\section{IMF Working Paper}

(C) 1998 International Monetary Fund
This is a Working Paper and the author(s) would welcome any comments on the present text. Citations should refer to a Working Paper of the International Monetary Fund. The views expressed are those of the author(s) and do not necessarily represent those of the Fund.

WP/98/88

INTERNATIONAL MONETARY FUND

African Department

\title{
The Price Incentive to Smuggle and the Cocoa Supply in Ghana, 1950-96
}

\author{
Prepared by Aleš Bulír ${ }^{1}$
}

Authorized for distribution by Jürgen Reitmaier

June 1998

\begin{abstract}
From the early 1960 s to the early 1980 s, the officially recorded production of cocoa in Ghana declined by 60 percent. During the 1983-95 Economic Recovery Program, however, cocoa production doubled. Although these developments have inspired much empirical research, most of the studies have been unable to explain the medium-term persistence of cocoa output to remain below its estimated capacity level. The paper argues that the price incentive to smuggle can explain as much as one-half of the observed decline in output and the subsequent recovery. A cointegration analysis and a dynamic error-correction model of cocoa supply support the analysis.
\end{abstract}

JEL Classification Numbers: C22, O55, Q11

Keywords: Ghana, cocoa supply, smuggling, commodity taxation, cointegration Author's Email Address: abulir@imf.org

${ }^{1}$ The author would like to thank to Rifaat Basanti, David Coe, Mark Dow, Stefania Fabrizio, Joachim Harnack, Matthew Jones, Lamin Leigh, Michael Nowak, and Thomas Walter, and participants in a seminar at the IMF. He remains, however, responsible for any remaining errors. 


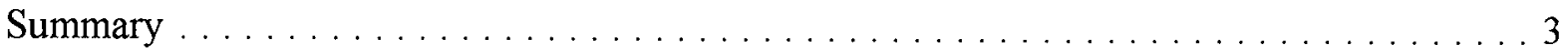

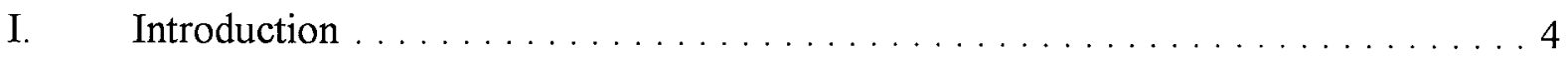

II. Cocoa Production in Ghana: A Review of Recent History $\ldots \ldots \ldots \ldots \ldots \ldots$

III. Taxation of Cocoa in Ghana $\ldots \ldots \ldots \ldots \ldots \ldots \ldots \ldots \ldots$

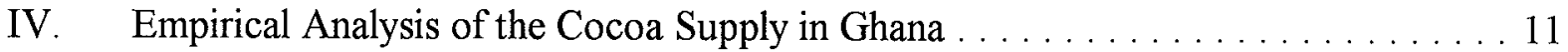

A. Research to Date ... . . . . . . . . . . . . . . . . . . . . . . 12

B. Determinants of Cocoa Supply in Ghana . . . . . . . . . . . . . 14

C. Empirical Results . . . . . . . . . . . . . . . . . . . . . 15

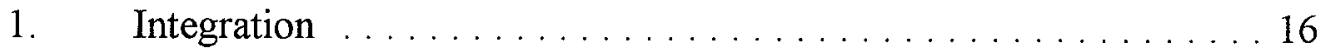

2. Cointegration ...................... 17

3. A single-equation model of cocoa supply . . . . . . . . . . . . . 19

D. Simulated Medium-Term Effects of Producer Price Changes . . . . . . . . 22

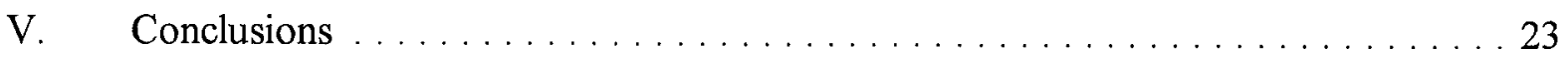

Figures

1. Cocoa Output Developments, $1950-96 \ldots \ldots \ldots \ldots \ldots \ldots \ldots$

2. Cocoa Price Developments, $1950-95 \ldots \ldots \ldots \ldots \ldots$

Tables

1. Cocoa Sector: Producer Income, Marketing Cost,

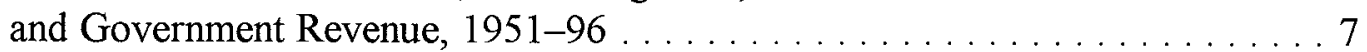

2. Projected and Actual Macroeconomic Developments, 1992/93-1994/95 . . . . . 9

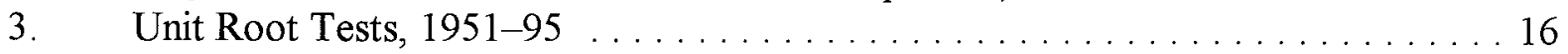

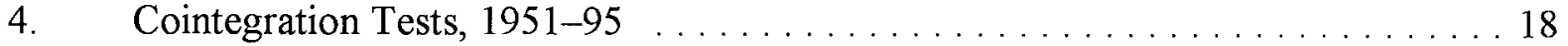

5. Cocoa Supply Regression Results, 1951-95 . . . . . . . . . . . . . . . . . 21

References .................................... 24 


\section{SUMMARY}

The paper examines the price-output relationship in Ghana's cocoa sector during the 1950-95 period. In the early $1980 \mathrm{~s}$, the officially recorded production of cocoa was 60 percent lower than during its peak in the early 1960s, and it remains below peak levels despite recent increases in production. Economic theory predicts that movements in the supply of an agricultural commodity depend on the relative return to the commodity. Although Ghana has been a price taker, the authorities have frequently intervened in the market, thereby driving a wedge between the international price and the domestic producer price. For much of the postindependence period, the taxation of cocoa producers in Ghana has been higher than in most other cocoa-producing countries.

Traditional studies based either on technological capacity functions or the partial adjustment supply model have been unable to explain the massive decline in the officially recorded output. Meanwhile, some have suggested that the long-term gap between "potential" and "actual" outputs - the "missing cocoa supply" - can be explained by cocoa smuggling to neighboring countries, notably to Côte d'Ivoire. A wealth of anecdotal evidence and persistent price differentials between Ghanaian and Ivoirien domestic markets support this hypothesis.

This paper examines the cocoa-smuggling hypothesis using the cointegration and error-correction techniques to establish long- and short-term cocoa supply functions. Cocoa supply is found to be cointegrated with international prices, which act as an expectation of producer prices, and with the Ghana-Côte d'Ivoire producer price differential, which proxies the motivation to smuggle. More than one-third of the deviation from the long-run equilibrium translates into the current supply decisions made by farmers. The short-run variations in output are not proportional to the Ghana-Côte d'Ivoire price differential, and smuggling seems to be based on long-term decisions rather than on immediate price signals. The price differential seems to explain some 40,000-60,000 metric tons of missing cocoa supply. 


\section{INTRODUCTION}

From the early 1960 s to the mid-1980s, the officially recorded production of cocoa beans in Ghana declined by 60 percent, and although it has begun to recover recently, it is still well below peak levels. This paper argues that the contraction of the Ghanaian cocoa sector can be explained by several external adverse factors and by the distortionary effect of domestic taxes, which, by widening the producer pace differential between Ghana and Côte d'Ivoire, increased the incentive to smuggle. On the one hand, real international cocoa prices receded from their peak levels in the late $1950 \mathrm{~s}$, the relative prices of competing domestic crops increased, and the sector experienced several years of severe drought in the 1970s and 1980 s. On the other hand, the cocoa sector has been badly affected by a high cocoa export duty and implicit taxes in the form of exchange rate distortions and marketing inefficiencies.

A number of empirical studies have investigated the response of the supply of cocoa in Ghana to exogenous factors. In fact, cocoa in Ghana is one of the most modeled commodities in the developing world. Three approaches to the modeling of cocoa can be distinguished: long-term technological capacity models, traditional partial-adjustment supply models, and models that take into account smuggling to neighboring countries. Following the third approach, this paper argues that as much as one-half of the supply fluctuations can be attributed to smuggling.

The paper is organized into four sections, as follows: historical developments in cocoa production in Ghana are reviewed in Section II; the effects of the direct and indirect taxation of cocoa in Ghana are evaluated in Section III; previous empirical studies are assessed, and a dynamic model of cocoa supply is estimated and used for short-term simulations in Section IV; and Section V reports our conclusions.

\section{COCOA PRODUCTION IN GHANA: A REVIEW OF RECENT HISTORY}

Cocoa has historically been the key economic sector in Ghana and a major source of export and fiscal revenue. However, recorded cocoa output declined from a peak in the early 1960 s of about $400,000-450,000$ metric tons, or more than 35 percent of world production, to barely 200,000 metric tons, or less than 10 percent of world production, in the early $1980 \mathrm{~s}$. While in 1960 Ghana produced five times more cocoa than its neighbor, Côte d'Ivoire, by early 1980s, Ghana's production was only one-third that of in Côte d'Ivoire (Figure 1). The impact of the contraction in cocoa production on Ghana's domestic and external imbalances was dramatic. The ratio of cocoa exports to GDP fell from about 20-25 percent in the early 1950 s to 5 percent in the early 1990s. Equally damaging was the loss of foreign exchange

receipts: the share of cocoa export receipts in total merchandise exports declined from $50-60$ percent in the late 1950 s to $20-30$ percent in the 1970 s, and fiscal revenue from the cocoa export duty declined accordingly. Cocoa output increased significantly after the launching of the Economic Recovery Program (ERP) in 1983 and it averaged 300,000 metric tons in 1990/91-1996/97 — still below the peak levels of the early 1960 s. 
Figure 1. Ghana: Cocoa Output Developments, 1950-96
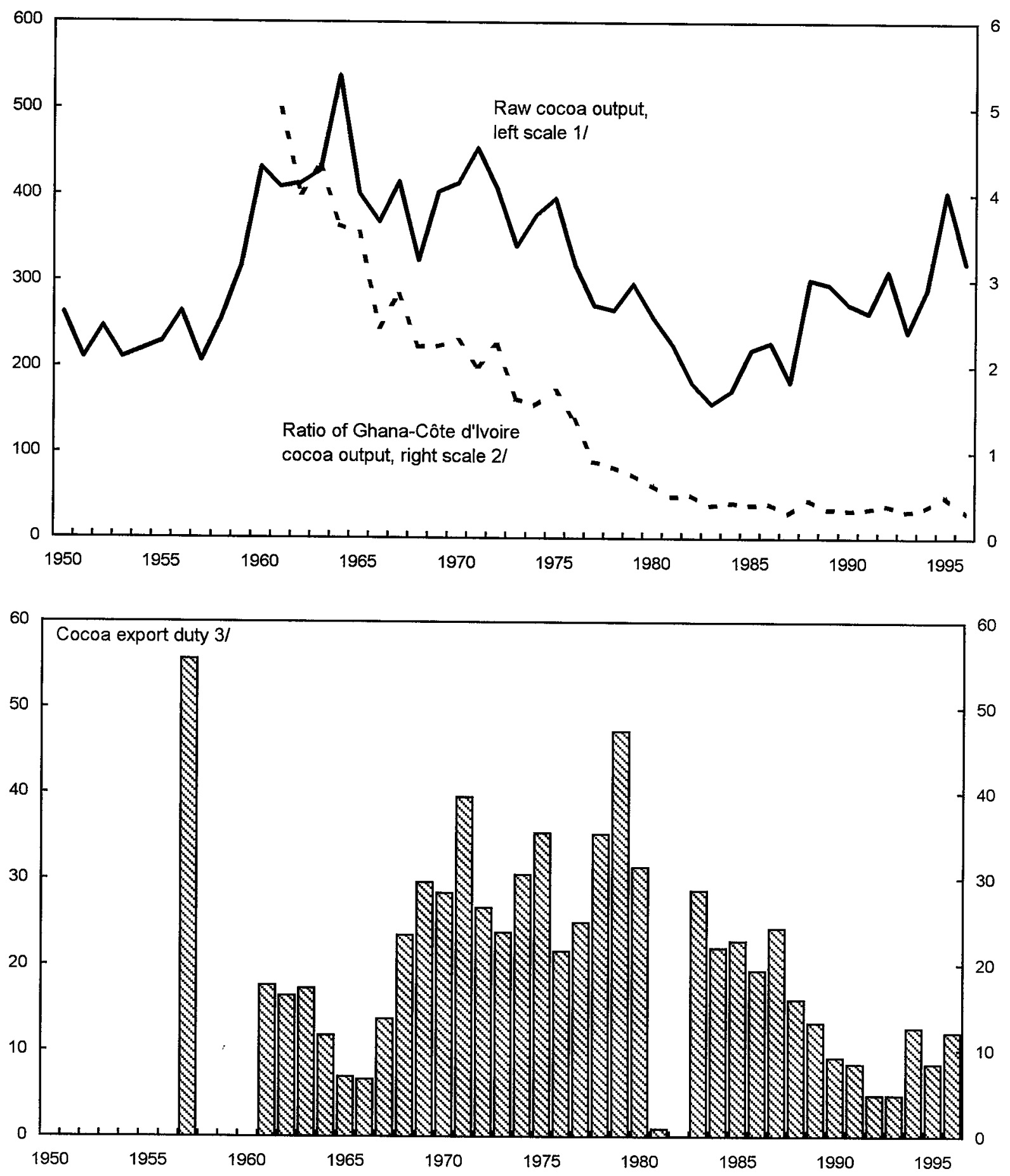

Sources: Cocoa Marketing Board (COCOBOD); and author's estimates.

1/ Official sales to COCOBOD; in crop years (ending in September), thousands of metric tons.

2/ In crop years (ending in September). 1950-59 production data for Côte d'Ivoire are not available.

3/ In percent of total government revenue; fiscal year (ending in December). Data for 1950-56 and 1958-60 are not available. 
Ghana is a price taker, and the world price and supply conditions of cocoa have a powerful impact on its cocoa sector. ${ }^{2}$ External developments can be characterized by a few stylized facts. Evidence suggests the existence of a 25 -year cocoa international price cycle, with the most recent troughs occurring in the early to mid-1960s and the mid-1980s (Weymar 1968, Bateman and others, 1990). Given the low income and price elasticities of world cocoa demand, large stocks of cocoa and recurrent oversupply have caused the real international cocoa price to decline by an average of almost 2 percent per annum since 1950. In addition, the global supply of cocoa beans is price inelastic in the short run-the time span between new plantings and their first crop is about three to five years, and trees bear beans for over 30 years with minimal maintenance and low harvesting cost. In the long run, however, supply has been sensitive to higher-than-average international prices because of new plantings: in 1957-64 and 1976-84, following spells of cyclically high prices, world output rose at annual rates of 9 percent and 6 percent, respectively.

Although cyclical price developments contributed to the initial contraction of the Ghanaian cocoa sector in the late 1960 s and early 1970 s, the macroeconomic policies pursued at the time by the government further aggravated the situation. As has been well documented in earlier studies, price and fiscal policies aiming at import substitution shifted the balance of incentives in the economy toward industry and nontradable goods and away from exportable goods (see Fosu (1992), Jaeger (1992), and Coleman, Akiyama, and Varangis (1993) for a review). Among agricultural producers, cocoa farmers were hardest hit: while between 1963 and 1980 the nominal producer price of cocoa rose 21 times, the respective prices of maize and rice rose 49 and 60 times. By way of comparison, international cocoa prices (in U.S. dollars) rose about ten times, while the exchange rate depreciated four times. The resulting price squeeze was further exacerbated by cost inefficiencies in the operations of the Cocoa Marketing Board (COCOBOD) that ultimately had to be borne by the farmers (Table 1). ${ }^{3}$ These unfavorable developments resulted in the virtual cessation of new plantings in the late 1960s and 1970s, and the aging of cocoa trees. ${ }^{4}$

${ }^{2}$ International prices have been controlled by the International Cocoa Organization (ICCO). This cartel intervened frequently in the market, and its price-smoothing interventions were, with the exception of 1980-83, mostly successful.

${ }^{3}$ At its peak, the COCOBOD had on its payroll over 100,000 ghost workers, and its share of total export proceeds was almost 40 percent. During the ERP, the payroll was reduced to below 20,000 workers without any discernible adverse impact on crop quality or the timeliness of deliveries.

${ }^{4}$ Still, there is evidence that cocoa farmers have remained richer than most of the other agricultural producers; see Roe and Schneider (1992). 


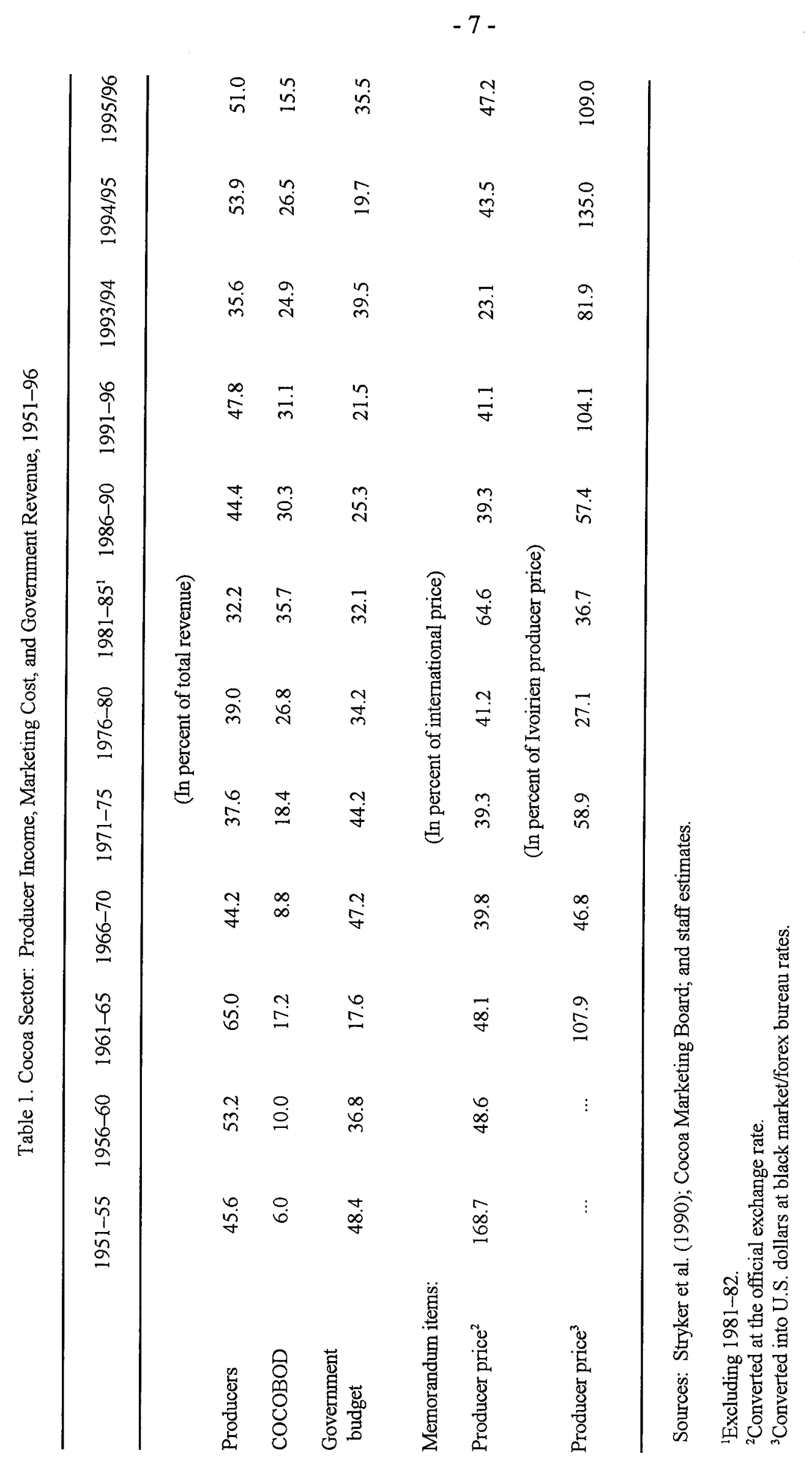


The effects of international prices and macroeconomic policies alone cannot explain, however, the 50 percent contraction in cocoa supply between 1960-65 and the early 1980.s. ${ }^{5}$ Assuming steady plantings in the past and a 30-year productive period for cocoa trees, in each year the productive capacity could have declined by only about 3-4 percent-that is, a ratchet effect was in place ${ }^{6}$ To get the above-mentioned contraction, there would have had to have been no new plantings for almost 20 years. Although new plantings and maintenance were neglected in some periods, there is no evidence of a 20-year planting shutdown. In fact, some studies have suggested that the decline in production was much smaller, at least in some regions, because of smuggling. Official COCOBOD estimates of smuggling are between 5-10 percent of the officially recorded crop, but in the late 1970s and early 1980s the amount smuggled may have been significantly higher in some border regions (May, 1985).

During the ERP, policies were introduced to reverse the decline in cocoa production. Increases in the producer price relative to neighboring countries weakened the incentive to smuggle, and a cyclically higher international price buttressed further the supply response. These policies met with some success: as of the mid-1990s, annual supply was almost double that of $1982 / 83$ crop, and the 1995/96 bumper crop yielded more than 400,000 metric tons.

\section{TAXATION OF COCOA IN GHANA}

Cocoa has traditionally been taxed by the government's collecting the difference between the expected international price and the cost of marketing the crop, which consists primarily of payments to farmers and the COCOBOD's operating expenses. ${ }^{7}$ Producer prices, which are set at the beginning of each crop season, have been set so as to achieve a certain share of export proceeds for farmers. In the mid-1990s, the government and the farmers' association negotiated for the farmers a 51 percent share, which was set to increase gradually to 60 percent by 2000 .

${ }^{5}$ By way of comparison, cocoa production in Côte d'Ivoire during the same period rose ninefold to about 1 million metric tons; see Akiyama (1988).

${ }^{6}$ These are fairly conservative assumptions. First, cocoa trees continue to bear fruits even after their prime productive age. Second, the cyclically high international prices in the late $1950 \mathrm{~s}$ and early 1960s spurred major plantings of trees, most of which were in their prime in the 1970 s and early 1980 s.

${ }^{7}$ Prior to 1951, the bulk of the difference between the international and producer prices was absorbed by the reserve fund of the COCOBOD. The reserve fund was used purely to stabilize the producer price--from 1950 to 1954, the producer price was more than double that of the international price. After being taken over by the government in the late 1950s, the reserve fund was depleted in the early 1960s. 
In the past, the assumptions used to calculate producer prices were often unrealistic. For example, the 1983 average black market exchange rate was about 80 cedis per U.S. dollar, and the so-called effective rate used for official transactions was only 2.75 cedis per U.S. dollar. ${ }^{8}$ Even in the 1990 s, the deviation between the macroeconomic projections, which are used to set the producer price, and the actual outcomes has been relatively high, and usually in favor of the government and against farmers (Table 2). Specifically, the farmers' share in real terms has been eroded by the faster-than-expected depreciation of the cedi and by higher-thanexpected inflation. Although farmers were compensated for those deviations, in 1992-95, according to COCOBOD information, the value of compensations was less than the actual loss. ${ }^{9}$

Table 2. Projected and Actual Macroeconomic Developments, 1992/93-1994/95 ${ }^{1}$

\begin{tabular}{|c|c|c|c|c|c|c|c|c|}
\hline & \multicolumn{2}{|c|}{$\begin{array}{l}\text { Inflation } \\
\text { (In percent) }\end{array}$} & \multicolumn{2}{|c|}{$\begin{array}{c}\text { Exchange Rate } \\
\text { (Cedis per U.S. dollar) }\end{array}$} & \multicolumn{2}{|c|}{$\begin{array}{l}\text { Rural Wage } \\
\text { (Cedis per day) }\end{array}$} & \multicolumn{2}{|c|}{$\begin{array}{l}\text { International } \\
\text { Price (F.o.b.) }\end{array}$} \\
\hline & Proj. & Act. & Proj. & Act. & Proj. & Act. & Proj. & Act. \\
\hline 1992/93 & 10.0 & 11.5 & 400 & 584 & 770 & 1,000 & 1,100 & 957 \\
\hline $1993 / 94$ & 8.0 & 25.0 & 650 & 882 & 1,080 & 1,500 & 950 & 1,235 \\
\hline $1994 / 95$ & 22.0 & 24.9 & 1,055 & 1,022 & 1,830 & 2,500 & 1,300 & 1,450 \\
\hline
\end{tabular}

Source: Cocoa Marketing Board.

${ }^{1}$ Crop year runs from October to September.

${ }^{2}$ U.S. dollars per metric ton.

The issue of an optimal long-run producer price, that is, the level of taxation, has been addressed many times (see, for example, Bateman and others, 1990). Since the mid-1970s, producer prices in Ghana were generally lower than the break-even point of the long-run planting cost. Producer prices averaged more than 50 percent of international prices in the 1950 s and early 1960 s, less than 40 percent in the late 1960 s and early 1970 s, before rising to over 40 percent in the 1980s (Table 1 and Figure 2). In real terms, however, 60 percent of the international price in the early 1980s was much less than 40 percent of the international price in the early 1970 s because of the secular decline in real international prices. In the $1990 \mathrm{~s}$, even

\section{${ }^{8}$ World Currency Yearbook (1986).}

${ }^{9}$ The compensation mechanism was activated when the actual forward international price at the moment of the trade was higher than the expected price that had been used earlier to compute the producer price. The aim of the mechanism is to defend the originally stipulated share of farmers in export proceeds. As a result, the government's share could shrink if the actual international price was less than expected. 
Figure 2. Ghana: Cocoa Price Developments, 1950-95

(Crop years; October-September)
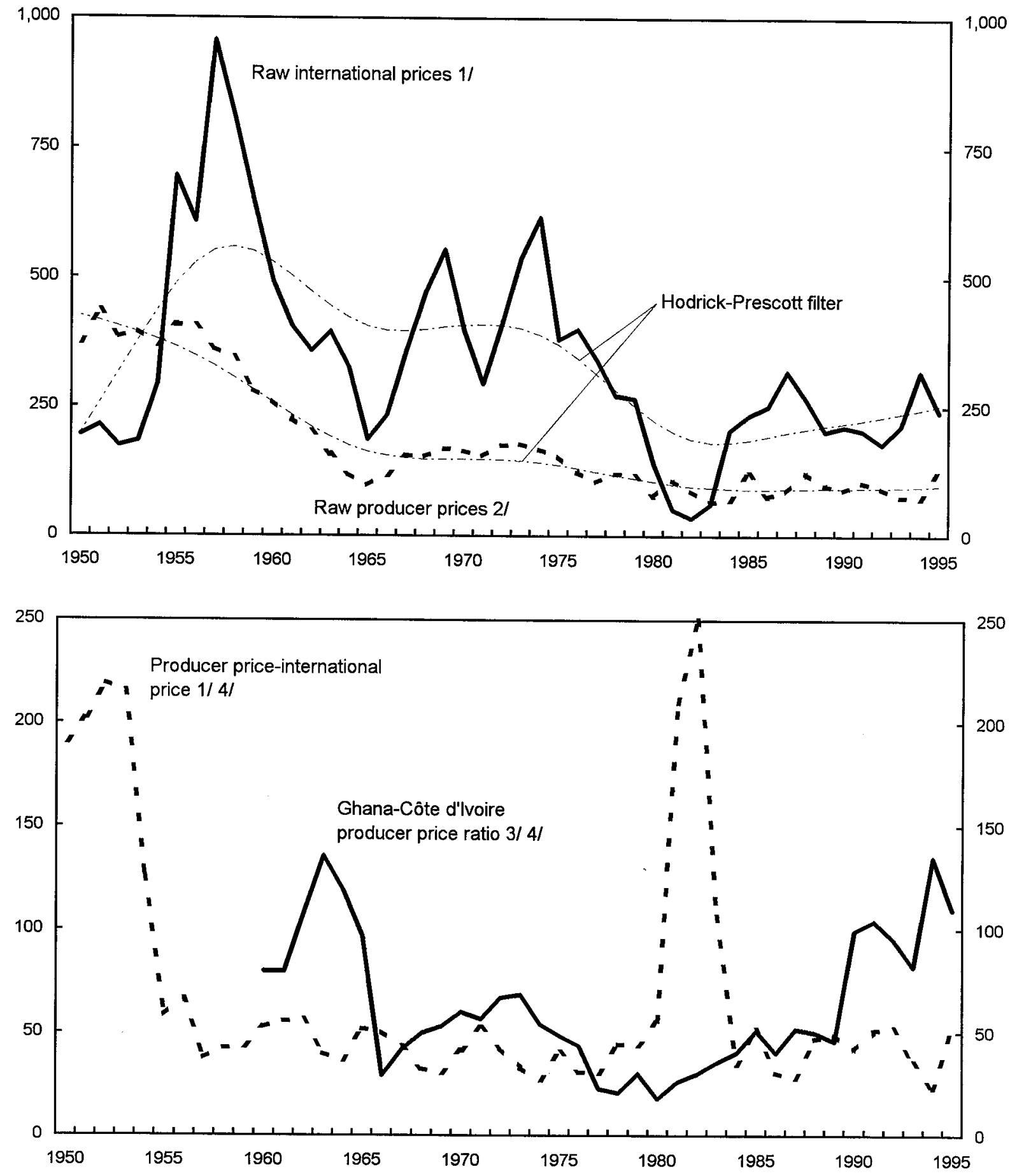

Sources: Cocoa Marketing Board; and author's estimates.

1/ Converted at the official exchange rate; in constant 1963 cedis.

2/ In constant 1963 cedis.

3 / Converted at the black market exchange rate.

4/ In percent. 
though the producer-international price ratio stayed low, the producer price has begun to be accompanied by ex post compensations to farmers as discussed above. Significantly, the producer-international price ratio was below the levels prevailing in the other cocoa-producing countries: producer prices in Brazil and Malaysia and-up to 1993-in Cameroon and Côte d'Tvoire averaged $60-80$ percent of international prices. ${ }^{10}$

The main objective of any taxation is to raise the maximum revenue without hampering growth in output. ${ }^{11}$ While a profit tax is generally best suited for this, it is perceived as difficult and costly to administer in a developing country's agricultural sector. Of course, well-known efficiency considerations are associated with export commodity taxes that may easily outweigh their advantages: commodity taxes affect the marginal rate of return more than their alternatives. ${ }^{12}$

It has been argued that the efficiency losses arising from export taxes may be limited if the crop supply is relatively inelastic with respect to price, that is, if the supply of rural labor is perfectly elastic and it is possible to switch only a little of the output away from cocoa. In Ghana, however, the empirical work presented below provides little or no evidence of price inelasticity in the long run. Anecdotal evidence offers some explanations of why this might be the case: Tabatabai (1986) finds that between 1-2 million rural workers migrated from Ghana in the 1970s; Konings (1986) argues that in the 1970s cocoa farmers shifted their lots from cocoa production to food crops, which suffered much smaller real price deterioration than cocoa; and May (1985) finds significant exchange-rate incentives for smuggling in the 1965-80 period.

\section{EMPIRICAL ANALYSIS OF THE COCOA SUPPLY IN GHANA}

A number of econometric analyses of cocoa supply and demand functions for Ghana have been undertaken since the 1960s. However, most of the research to date suffers from the problems associated with the estimation of nonstationary time series and the arbitrary selection of lag structures; accordingly, these models have been unable to explain the massive decline in recorded cocoa output. After a brief review of the previous results, a model of cocoa supply

\footnotetext{
${ }^{10}$ Côte d'Ivoire, for example, has fixed the producer price in nominal terms well above the long-term planting cost; occasionally, when the international price has been low, it has repealed the tax altogether.

${ }^{11}$ In principle, the optimal short-run export tax is simply a function of the world elasticity of demand and the country's share in world production. In the long run, the optimal export tax should take into account also the impact of new international prices on other producers and the speed with which this affects planting and production.

${ }^{12}$ For a further discussion of commodity taxation, see Bateman and others (1990) and Bulír (1996).
} 
determination is described and estimated that, using a simple error-correction technique for the sample period 1950-95, invokes smuggling to other countries to explain the missing cocoa supply.

\section{A. Research to Date}

The studies can be divided into three broad groups. First, some studies model the supply of cocoa as a "technological" function of the stock of cocoa trees and fertilization efforts. The resulting long-run or technological capacity function is usually accompanied by a short-run function that takes into account price and weather shocks. Second, a traditional partial-adjustment supply model has been used with properly defined own and cross elasticities of domestic producer prices. Finally, a few studies have estimated the supply response of cocoa to changes in producer prices in neighboring countries. These studies have generally found that smuggling explains supply fluctuations better than most other variables.

Important contributions to the first group (technological capacity models) have been made by Merrill Bateman. As a first step, he estimated a long-run production capacity equation for Ghana based on tree yields and several variables measuring the chemical spraying of cocoa trees that had a built-in ratchet effect (Bateman, 1974). As a second step, his short-run supply function included the previously estimated production capacity, real producer prices, and three rainfall variables. Both equations were estimated separately for the three major cocoaproducing regions in Ghana, and the short-term price elasticities of supply were found to be of a similar magnitude, ranging from 0.14 to 0.22 . Those results were later replicated in Bateman and others (1990). Another example of the technology-driven approach to estimating the supply of cocoa is Gyimah-Brempong (1987).

There are three problems with this approach. First, data on new plantings are scarce and unreliable -satellite pictures have shown larger areas under cocoa cultivation than previously reported by the COCOBOD. Second, combining the separately estimated long- and short-run output functions might cause serious identification problems when estimating by ordinary least squares (see Wilson (1984)). Third, the estimates seem unable to explain the medium-term persistence of officially reported cocoa output above or below its capacity level (the so-called missing cocoa supply).

The second and largest group of empirical studies has relied on the traditional partial-adjustment model using several domestically determined explanatory variables. (See, for example, Abbey and Clark (1974), Yeung, Pollak, and Augusto (1979), Berthelemy and Morrisson (1987), and Stryker and others (1990)). In these studies, the estimated equations and the results of those estimates are similar. As a representative example, Stryker and others have regressed the actual production on its lagged value, an estimate of cocoa production capacity, producer prices of cocoa, and producer prices of competing food crops. The estimated own short- and long-run producer price elasticities were 0.22 and 0.62 , respectively, and the cross-price elasticities were poorly estimated, at -0.14 and -0.40 , respectively. In 
addition, some authors have included the supply of manufactured goods to capture the impact of goods market rationing on the farmers' motivation to produce. ${ }^{13}$

The problems with this approach — as with the technological capacity models-are threefold. First, the inability of farmers to substitute for cocoa in the short run explains the statistical insignificance of short-term cross-price elasticities in many studies (Wilson, 1984; and Stryker and others, 1990). Of course, if the producer price is below the (short-run) harvesting cost, farmers might choose not to collect their crops. Second, the partial adjustment model used in most estimates leads to spurious regressions if the data are nonstationary. This problem has recently been corrected by Abdulai and Rieder (1995), who apply cointegration and error-correction techniques to the previously described model. Third, and most important, the models are still unable to explain the missing cocoa supply. For example, in the Stryker model the actual output was on average lower by 16 percent than the potential production in 1965-75, and the average gap rose to 32 percent (!) in the next decade.

The third group of authors has focused on the price incentive to smuggle to explain why the officially recorded cocoa production stayed for several years above or below its estimated production capacity. ${ }^{14}$ These authors realize that cocoa is a cash crop that can be easily smuggled, because the borders with Côte d'Ivoire and Togo are practically unguarded. As early as in 1982, Akiyama and Duncan regressed cocoa output on real prices (both in firstorder differences) and a rainfall variable; in addition, their equation included three variables lagged one year: cocoa output, real producer prices, and the Ghana-Côte d'Ivoire price differential (all in levels). ${ }^{15}$ Both short- and long-run domestic producer price elasticities were low and statistically insignificant. However, their model has shown the strong impact of price developments in Côte d'Ivoire: raising the price differential by 1 percent lowered the Ghanaian supply of cocoa by one-quarter of 1 percent. In other words, official sales to the COCOBOD might have fluctuated because of smuggling rather than changes in cocoa output. These

${ }^{13}$ Analytical background for this variable was provided by Bevan and others (1989). Arguments put forward by Abdulai and Rieder (1995) raise, however, some doubts about the value of this variable in Ghana's context. Why would farmers revert to subsistence production or smuggling in order to obtain goods rationed in Ghana? Would it not be easier to produce cocoa, exchange the export proceeds into dollars, and smuggle goods, as suggested by Azam and Besley (1989)? Notwithstanding the Granger causality estimated by these authors, both the supply of manufactured goods and cocoa might be driven by a third variable, say, overall macroeconomic conditions. A real exchange rate appreciation affects manufacturing as well, even though its impact, through the availability of foreign exchange for imported inputs, is slower than its impact on agricultural exports.

${ }^{14}$ Sheikh (1989) provides a useful summary of the existing models of smuggling.

${ }^{15}$ This is effectively an error-correction mechanism. An unrestricted estimation using ordinary least squares is, however, not the proper way to proceed (see Charemza and Deadman (1992)). 
findings have been confirmed by Fosu (1992), who estimated the short-term elasticity of Ghana's cocoa exports with respect to the Ghana-Côte d'Ivoire price differential at about $0.17 .{ }^{16}$ May (1985), in estimating the regional motivation to smuggle cocoa to neighboring countries, finds that as much as 50 percent of the crop in some regions may have been smuggled either to Côte d'Ivoire or to Togo. As a result, he finds that virtually all new cocoa plantings in Ghana in the 1970s and 1980s were made in areas adjacent to Côte d'Ivoire and Togo in order to minimize the cost of transporting smuggled cocoa. Azam and Besley (1989) formulate and test a general equilibrium model of Ghana's economy that features parallel foreign exchange and consumer good markets, and cocoa smuggling.

In this paper, we follow the third approach, using correct estimation techniques, because it seems best suited to explain the short- to medium-run fluctuations in the officially recorded cocoa output. As shown by developments in Côte d'Ivoire's cocoa sector, if producer prices are above the long-run planting cost and regionally competitive, new plantings, cocoa output, and exports grow at a steady rate (Akiyama, 1988).

\section{B. Determinants of Cocoa Supply in Ghana}

The supply of cocoa is ultimately a function of relative producer prices, even though short-term production capacity is constrained and output may fluctuate because of weather conditions. Producer prices signal changes in the expected return on cocoa. Therefore, they affect plantings and crop outputs, as well as farmers' decisions to sell domestically or to smuggle. The farmers might even decide not to collect the current crop if the offered producer prices are too low. This study measures the price incentives by three variables: the real international price, the real producer price, and the differential between Ghanaian and Ivoirien producer prices in U.S. dollar terms (Figure 2). Both producer and international prices were deflated by the consumer price index. International prices were converted into cedis at the official exchange rate because this rate was used by the COCOBOD to calculate producer prices. The Ghana-Côte d'Ivoire price differential, however, was computed using the black market exchange rate from the World Currency Yearbook for the period before the exchange rate liberalization in the mid-1980s and the foreign exchange bureaus' rate for the period afterward: if farmers smuggle cocoa to Côte d'Ivoire or Togo, they are paid in CFA francs, which they have to exchange into U.S. dollars and ultimately into cedis.

The rationale behind using these three price indicators to measure price incentives is as follows. First, the real international price conveys information about secular and cyclical price developments and signals the expected return on cocoa production ${ }^{17}$ Notwithstanding

\footnotetext{
${ }^{16}$ The earlier objection to the estimation of nonstationary time series applies to Fosu (1992), too.

${ }^{17}$ However, Bateman (1974) notes that the preindependence producer prices were "ineffectively" high, that is, well above both the long-term planting cost and international
} 
fluctuations in the producer price independent of international price developments, producer prices will over time mirror international prices, and the latter can therefore be treated as an expectation of the former. Therefore, an increase in real international prices should lead to an increase in output. Second, the real producer price measures the rate of return of farming cocoa relative to other crops, the prices of all of which are assumed to move with inflation. ${ }^{18}$ The increase in producer prices (own price elasticity) should lead, of course, to an increase in output. Finally, the ratio of Ghanaian to Ivoirien producer prices, called the smuggling incentive, measures the rate of return on cocoa sold domestically compared with that of cocoa smuggled to Côte d'Ivoire. Closing the wedge between producer prices should also increase output. In the pre-ERP period, Ghanaian farmers were motivated to smuggle cocoa both by higher producer prices (relative to international prices) in Côte d'Ivoire and Togo and by the overvalued official exchange rate. During the ERP period, when exchange rates were liberalized, the main motivation to smuggle came from lower domestic producer prices (higher cocoa export duty).

\section{Empirical Results}

The study uses data from various sources. For the pre-1990 observations of output and domestic and international prices, we used time series published by Stryker and others (1990); for the 1960-82 observations of the Ghana-Côte d'Ivoire price differential, May (1985). For subsequent observations, we used data published by the IMF (in Nowak and others, 1996) and the World Currency Yearbook, respectively. However, the collapse of international prices in 1980-82 and the devaluation of the cedi in 1983 generated a potential measurement problem. In our model, international prices operate as an expectation of domestic prices, and those expectations obviously did not decline six times in real terms between 1979 and 1982. To correct for the 1980-82 "outliers," in the regressions presented below we replaced these observations by a Hodrick-Prescott filter. In any case, the measurement problem did not seem to affect the estimated coefficients. Whether we used raw international prices, raw data with 1980-83 observations replaced by a Hodrick-Prescott filter, or the complete international price series filtered by a Hodrick-Prescott filter, the estimates were affected little. ${ }^{19}$

${ }^{17}$ (...continued)

prices (see Figure 2). Such a high price resulted in windfall profits, not more planting efforts. As a result, the information value of international prices for the expected return on cocoa was limited. Producer prices exceeded international prices also in 1981-83. During this period, however, the COCOBOD's payments were effected in the official exchange rate that was 10-20 times higher that black-market exchange rates.

${ }^{18}$ The preferred price index would include food or agricultural components only. However, such a time series is not available for the period under consideration.

${ }^{19}$ The only discernible effect was a faster speed of adjustment to the changes in the long-run equilibrium if the raw international price series was replaced with a Hodrick-Prescott filter. 


\section{Integration}

Before modeling time series, it is useful to determine the orders of integration for the variables considered (all variables, except for the Ghana-Côte d'Ivoire price differential, are in natural logarithms). Table 3 lists first-order augmented Dickey-Fuller statistics for cocoa output, producer and international prices, and the smuggling incentive. The estimated root appears in parentheses below each augmented Dickey-Fuller statistics: this number should be close to one if the series has a unit root. Unit root tests are given for each variable in levels and for their changes, and this permits testing whether a given series is $I(0)$ or $I(1)$, respectively.

Empirically, all variables seem to be integrated of order one. The international cocoa price appears to be stationary, that is, $\mathrm{I}(0)$, if inferences are made on the Dickey-Fuller statistics alone. However, the estimated root for the international cocoa price variable in levels is 0.7 , which numerically is quite close to unity, and also visual evaluation (Figure 2) suggests a possibility of random walk properties. Thus, all four series are treated below as if they are I(1), while recognizing that some caveats may apply.

Table 3. Unit Roots Tests, 1951-95

\begin{tabular}{lcccc}
\hline \multirow{2}{*}{$\begin{array}{l}\text { Order of } \\
\text { Integration }\end{array}$} & \multicolumn{4}{c}{ Variable } \\
\cline { 2 - 5 } & Cocoa supply & Producer price & International price & $\begin{array}{l}\text { Smuggling } \\
\text { incentive }\end{array}$ \\
\hline I(0) & -1.78 & -1.95 & $-3.28^{*}$ & -2.37 \\
& $(0.83)$ & $(0.88)$ & $(0.70)$ & $(0.70)$ \\
$\mathrm{I}(1)$ & $-5.39^{* *}$ & $-5.65^{* *}$ & $-4.40^{* *}$ & $-3.89^{* *}$ \\
& $(-0.32)$ & $(-0.39)$ & $(0.14)$ & $(-0.20)$ \\
\hline
\end{tabular}

Source: Author's calculations.

${ }^{1}$ Augmented Dickey-Fuller test with one lag and the estimated coefficient on the lagged variable in the Dickey-Fuller equation (in parentheses). Asterisks * and ${ }^{* *}$ signal the rejection of a unit root at the 5 percent and 1 percent critical values, respectively.

${ }^{2}$ The number in parentheses denotes the order of differentiation of each variable. 


\section{Cointegration}

Cointegration analysis helps clarify the long-run relationship between integrated variables. We employed the maximum likelihood procedure for finite-order vector autoregressions (VARs) developed by Johansen and Juselius (1990). ${ }^{20}$ Empirically, the lag of the VAR is not known a priori, but has to be established. By sequentially reducing and testing the order of VARs, we simplified the cointegrating relationships to a first-order VAR. Two cointegrating relationships were tested: the international-domestic price pass-through and the long-run cocoa supply functions.

First, the paper hypothesized that domestic producer prices follow the international cocoa price developments. To test this hypothesis, we tested the existence of a long-run relationship between international and domestic producer prices, namely the cointegrating relationship and the direction of Granger causality. Even though only about one-fourth to one-third of the change in the international price was transmitted to the contemporaneous producer price, the two variables are clearly cointegrated (we do not report the full set of results here). Moreover, international prices are weakly exogenous, and international prices are Granger prior to domestic producer prices. ${ }^{21}$ The likelihood ratio tests of cointegration were well above their critical values. Hence, the hypothesis of international prices as longer-term expectations of domestic producer prices seems to be justifiable.

Second, we established a long-run relationship between the supply of cocoa and various measures of real prices. Given subsidized producer prices in the preindependence period and the absence of information on the Ghana/Cote d'Ivoire price differential for 1950-59, we present our results for both the full sample and the 1960-95 subsample. We estimate the longrun cocoa supply function based on variables measuring the expected return on cocoa:

Supply $=\beta_{1}$ International price $+\beta_{2}$ Producer price $+\beta_{3}$ Smuggling incentive $+\alpha$.

The results confirm that cocoa developments are price driven in the long run: the supply of cocoa, international prices, and the smuggling incentive are said to be cointegrated in a unique vector (Table 4). However, domestic producer prices do not seem to be a part of a cointegrating vector: the estimated long-run coefficients of producer prices are not significantly different from zero and the long-run supply functions comprising producer prices are marginally significant only for the 1960-95 subsample (those results are not reported here). These findings support the earlier discussed hypotheses that the information content of the international price dominates that of the producer price and that other crops are not long-run substitutes for cocoa production.

\footnotetext{
${ }^{20}$ Procedures for estimating equations with nonstationary variables have been developed in Engle and Granger (1987) and Johansen and Juselius (1990).

${ }^{21}$ While the hypothesis of international prices Granger causing producer prices can be rejected only at the 21 percent significance level, the opposite hypothesis can be rejected at the 2 percent significance level. Both hypotheses use the vector autoregression (VAR) technique with one lag and the likelihood ratio test for variable deletion.
} 
Table 4. Cointegration Tests, 1951-95

(Regressions with one lag, unrestricted intercepts, and no trends in the VAR) ${ }^{1}$

(i) Full sample period

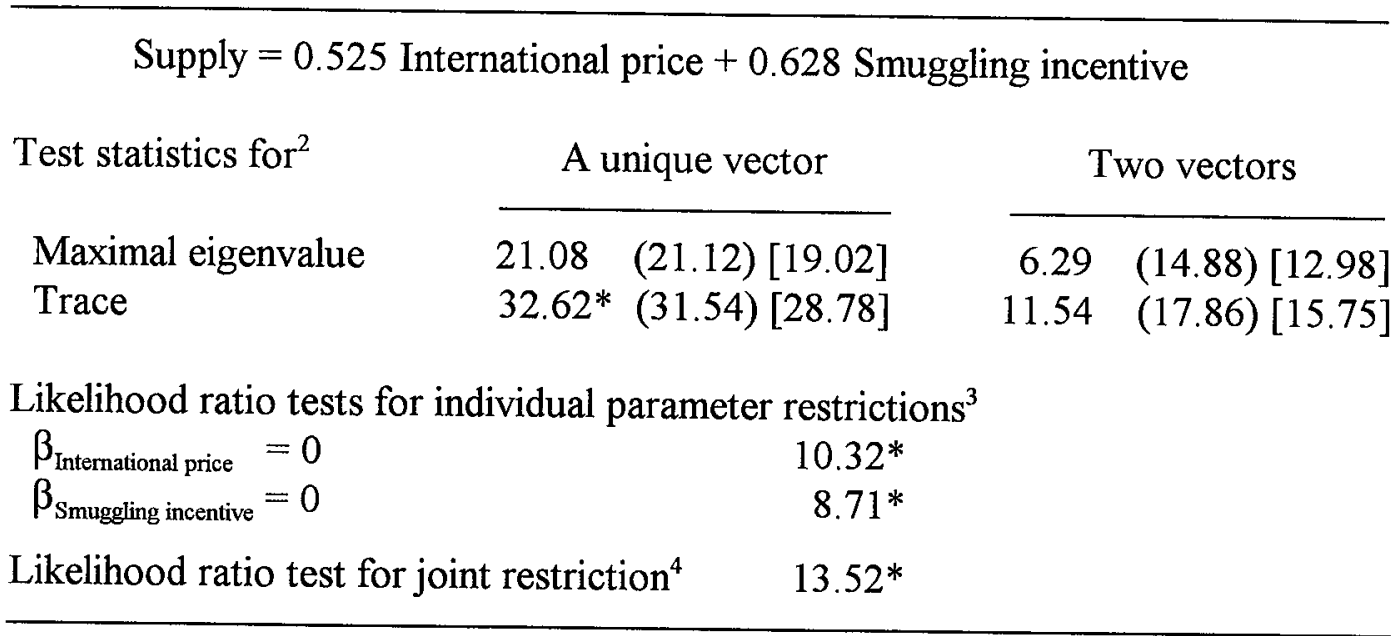

(ii) 1960-1995 sample period

Supply $=0.640$ International price +0.713 Smuggling incentive

Test statistics for ${ }^{2}$

Maximal eigenvalue

Trace
A unique vector

$\begin{array}{ll}21.11 & (21.12)[15.57] \\ 32.45 * & (31.54)[28.78]\end{array}$

Two vectors

$8.51 \quad(14.88)[12.98]$

$11.35(17.86)[15.75]$

Likelihood ratio tests for individual parameter restrictions ${ }^{3}$
$\beta_{\text {Intemational price }}=0$
$\beta_{\text {Smuggling incentive }}=0$
9.08*
$10.91 *$

Likelihood ratio test for joint restriction ${ }^{4} \quad 16.27^{*}$

Source: Staff calculations.

${ }^{1}$ A general to specific approach was applied.

${ }^{2}$ Critical values for likelihood ratio tests at the 95 percent and 90 percent significance level in parentheses and brackets, respectively. A "*" signals significance at the 95 percent level.

${ }^{3}$ Individual parameters of the right-hand side variables are restricted to zero. A "*" denotes rejection of this restriction at the 95 percent level.

${ }^{4}$ All parameters of the right-hand side variables are restricted to zero. $\mathrm{A}^{* * *}$ denotes rejection of this restriction at the 95 percent level. 
Those qualitative findings will be used in the next section to formulate an error-correction model of cocoa supply.

All coefficients have their anticipated signs and their numerical values are analogous to those in earlier studies. The normalized elasticity and semielasticity of supply with respect to the international price and to the Ghana-Côte d'Ivoire price differential are close to $0.5-0.6$ and $0.6-0.7$, respectively (Table 4). ${ }^{22}$ Individual and joint statistical significance of both parameters are successfully tested.

\section{A single-equation model of cocoa supply}

This section presents the estimation results for a parsimonious single-equation model of cocoa supply, with the error-correction term embedded. Because international prices are used as a proxy for expectations of domestic producer prices, the former do not enter the short-run portion of the error-correction model (first row of equation 2); correspondingly, domestic producer prices do not enter the long-run portion of the model (second row of equation 2 ). The general equation with a choice of lags was specified as follows:

$$
\begin{gathered}
\Delta \text { Supply }_{t}=\alpha+\sum_{i=0}^{k} \beta_{1 i} \Delta \text { Producer price }{ }_{t-i}+\sum_{i=0}^{k} \beta_{2 i} \Delta \text { Smuggling incentive }_{t-i}+ \\
\gamma\left(\text { Supply }_{t-1}-\delta_{1} \text { International price }_{t-1}-\delta_{2} \text { Smuggling incentive }_{t-1}\right)+\epsilon_{t}
\end{gathered}
$$

where $\gamma$ is the parameter of the error-correction term (in parentheses), which captures the speed of adjustment to disequilibrium conditions; $\Delta$ is a first-difference operator; and $\epsilon$ is an error term.

The feed-through of the previous period's departures from long-run equilibrium into current-period supply developments is based on the notion that the cocoa supply does not adjust instantaneously to the desired levels consistent with the international price and the Ghana-Côte d'Ivoire price differential. One reason for this partial adjustment of cocoa supply is the cost of gathering information on international and Ivoirien producer prices, and on expected exchange rates. Uncertainty about the transaction and transportation costs of smuggling would be a second reason. ${ }^{23}$ Finally, new plantings - as well as switching output from cocoa to other crops, and vice versa-are time-consuming and costly.

\footnotetext{
${ }^{22}$ The long-run matrix $\pi$ can be written as $\alpha \beta^{\prime}$, where $\alpha$ and $\beta$ are $\boldsymbol{k} \times 1$ vectors. We normalize the long-run coefficients $\boldsymbol{\beta}^{\prime}$ as $\left(1,-\boldsymbol{\delta}^{\prime}\right)$ and partition the adjustment matrix as $\alpha^{\prime}=\left(\alpha_{1}, \alpha_{2}\right)$.

${ }^{23}$ For example, in the early 1980 s, the Ghanaian government attempted, albeit unsuccessfully, to close the borders with Côte d'Ivoire and Togo.
} 
The general equation (2) was successfully simplified to a version in which only current changes in producer prices and the Ghana-Côte d'Ivoire price differential matter for short-term output decisions (Table 5). The results correspond both to a priori economic assumptions and to the previously estimated cointegrating relationship: the long-run elasticity and semielasticity of supply with respect to the international price and to the Ghana-Côte d'Ivoire price differential are between 0.59 and 0.67 and between 0.44 and 0.67 , respectively. The speed of adjustment to long-run price changes, as measured by the coefficient of the error-correction term, suggests that about one-third to one-half of the deviation from the long-run equilibrium in the previous year translates into the current supply decisions made by farmers. ${ }^{24}$ As found in previous studies, the short-run producer price elasticity is below one-third (0.19-0.32), and significant at the 95 percent level only when the Ghana-Côte d'Ivoire price differential is included. The short-run semielasticity of the Ghana-Côte d'Ivoire price differential is even lower and is marginally significant only when the change in producer price is included.

The error-correction model confirms that smuggling, stimulated by the Ghana-Côte d'Ivoire price differential, played an important role in the two adjacent markets. As a rule of thumb, a doubling of the smuggling incentive-say, from 0.7 in the early 1970 s to 0.3 in the late $1970 \mathrm{~s}$-reduces the officially recorded supply of cocoa by $40,000-60,000$ metric tons. In other words, smuggling might explain as much as one-half of the output decline.

Furthermore, two tentative conclusions regarding short-term cocoa output substitution and smuggling can be made. First, given the absolute value of the Ghana-Côte d'Ivoire price differential, any further decline in the real domestic producer price motivates Ghanaian farmers to increase the amount of cocoa smuggled (or not to collect the crop at all if both the Ghanaian and Ivoirien producer prices are below the short-term harvesting cost and transportation cost). As discussed earlier, output of food crops cannot be quickly substituted for that of cocoa, or vice versa. Farmers can, however, change the proportion of their efforts directed at cocoa and food crops, assuming, of course, that labor and both cocoa and food lots are less than fully utilized. Second, smuggling appears to be costly in the short run as farmers must gather information and enter into across-the-border contracts that lack reputation: the short-run variations in output are not proportional to the Ghana-Côte d'Ivoire price differential. In other words, smuggling seems to be based on long-term decisions rather than on immediate price signals. ${ }^{25}$

${ }^{24}$ This speed of adjustment is much less than that reported by Akiyama and Duncan (1982). Their estimate, however, is most likely biased because an incorrect estimation technique was used.

${ }^{25}$ This hypothesis might also explain why there was little or no smuggling of cocoa from Côte d'Ivoire to Ghana in 1990-91 and 1994-95, when Ghanaian producer prices were marginally higher than those in Côte d'Ivoire. 
Table 5. Cocoa Supply Regression Results, 1951-95 (Absolute value t-statistics in parentheses)

\begin{tabular}{|c|c|c|c|c|}
\hline \multirow[t]{2}{*}{ Variable } & \multicolumn{2}{|c|}{ Equation A } & \multicolumn{2}{|c|}{ Equation $\mathrm{B}$} \\
\hline & $1951-95$ & $1960-95$ & $1951-95$ & $1960-95$ \\
\hline & \multicolumn{3}{|c|}{ (Short-run dynamics) } & \\
\hline Constant & $\begin{array}{c}0.707 \\
(1.36)\end{array}$ & $\begin{array}{c}0.726 \\
(1.31)\end{array}$ & $\begin{array}{l}0.795 \\
(1.55)\end{array}$ & $\begin{array}{r}0.668 \\
(1.25)\end{array}$ \\
\hline $\begin{array}{l}\text { Producer price, } \\
\text { first difference }\end{array}$ & $\begin{array}{r}0.187 \\
(1.64)\end{array}$ & $\begin{array}{r}0.203 \\
(1.78)\end{array}$ & $\begin{array}{l}0.267 \\
(2.18)^{*}\end{array}$ & $\begin{array}{c}0.317 \\
(2.56)^{*}\end{array}$ \\
\hline \multirow[t]{2}{*}{$\begin{array}{l}\text { Smuggling incentive, } \\
\text { first difference }\end{array}$} & & & $\begin{array}{l}0.180 \\
(1.62)\end{array}$ & $\begin{array}{r}0.237 \\
(1.93)\end{array}$ \\
\hline & \multicolumn{4}{|c|}{ (Long-run equilibrium relationship) } \\
\hline Error correction term & $\begin{array}{l}-0.360 \\
(3.46)^{*}\end{array}$ & $\begin{array}{l}-0.445 \\
(3.52)^{*}\end{array}$ & $\begin{array}{l}-0.390 \\
(3.75)^{*}\end{array}$ & $\begin{array}{l}-0.439 \\
(3.64)^{*}\end{array}$ \\
\hline $\begin{array}{l}\text { International price, } \\
\text { lagged once }\end{array}$ & $\begin{array}{l}0.611 \\
(3.41)^{*}\end{array}$ & $\begin{array}{l}0.657 \\
(3.72)^{*}\end{array}$ & $\begin{array}{c}0.591 \\
(3.70)^{*}\end{array}$ & $\begin{array}{l}0.665 \\
(3.88)^{*}\end{array}$ \\
\hline $\begin{array}{l}\text { Smuggling incentive, } \\
\text { lagged once }\end{array}$ & $\begin{array}{l}0.444 \\
(2.57)^{*}\end{array}$ & $\begin{array}{l}0.532 \\
(2.86)^{*}\end{array}$ & $\begin{array}{c}0.538 \\
(3.25)^{*}\end{array}$ & $\begin{array}{l}0.670 \\
(3.36)^{*}\end{array}$ \\
\hline $\mathrm{R}^{2}$ & 0.369 & 0.431 & 0.409 & 0.498 \\
\hline Adjusted $\mathrm{R}^{2}$ & 0.306 & 0.352 & 0.335 & 0.408 \\
\hline Durbin-Watson & 2.165 & 2.316 & 2.255 & 2.490 \\
\hline S.E. of regression & 0.150 & 0.143 & 0.147 & 0.137 \\
\hline Heteroscedasticity $\chi(1)$ & 0.006 & 0.469 & 0.196 & 0.025 \\
\hline
\end{tabular}

Source: Staff calculations. level.

${ }^{1}$ Estimation is by nonlinear least squares. $\mathrm{A}{ }^{* * 1}$ signals significance at the 95 percent 


\section{Simulated Medium-Term Effects of Producer Price Changes}

We then used the estimated model presented in Table 5 (equation A, covering the 1960-95 sample) to answer two policy questions. First, can the expected initial positive effect of lower producer prices on government revenue be sustained? Second, how would a higher (and stable) farmers' share of international prices affect the supply of cocoa and government revenue in the medium term? ${ }^{26}$

First, the results show that lower producer prices will only temporarily boost government revenue. Consider a situation in which the Ghanaian producer price is unexpectedly lowered, ceteris paribus, by 10 percent to increase government revenue from cocoa export duty. How will the consequent changes in the supply of cocoa be distributed over time? In the first year, supply will drop by about 4-5 percent, owing to the lower producer price (inputs will be switched to other crops, or cocoa crops yielding submarginal returns will not be harvested) and owing to a bigger Ghana-Côte d'Ivoire price differential (output will be smuggled). Hence, government revenue will increase by 5-6 percent only. In the second year, farmers will adjust their long-run equilibrium supply downward by $30-40$ percent of the initial disequilibrium and the actual supply will drop by another 3-4 percentage points. The revenue effect of lower producer prices will thus be entirely dissipated in two years; after that, government revenue will decline from its initial level as supply continues to drop.

Second, the supply of cocoa seems responsive to higher domestic producer prices, providing that changes in the producer price are reflected in the smuggling incentive. If producer prices stabilize in 1996-2000, say, at 55 percent of the 1996 international price (compared with the 1995-96 ratio of about 50 percent) and the Ghana-Côte d'Ivoire price gap is completely closed, then, ceteris paribus, the supply of cocoa would rise to 440,000 metric tons in 2000 from 320,000 metric tons in 1995. As a result, government revenue would increase by about 15 percent between 1996 and $2000 .{ }^{27}$ However, too high an increase in the producer price would not raise supply by much in the medium term and would be detrimental to government finances. For example, raising the farmers' share to 65 percent would increase the annual supply only to about 460,000 metric tons, and government revenue would decline by 30 percent.

\footnotetext{
${ }^{26} \mathrm{We}$ constrain our simulations to the medium term in order to avoid modeling international price effects on the potential output. In the long run, a bigger Ghanaian contribution to the world supply of cocoa is likely to depress international prices. See Weymar (1968) for an introduction to the determination of cocoa international prices.

${ }^{27}$ For the sake of simplicity, we assume that the COCOBOD cost would stay at 20 percent of the international price. The results would be identical, if the COCOBOD cost dropped to 15 percent and the producer price rose accordingly.
} 


\section{Conclusions}

Multiple effects were at play in the decline of Ghana's share in world cocoa output between the early 1960s and the early 1980s. Nevertheless, the most important factor adversely affecting the cocoa sector was the government's policies: in the late 1960s and in the 1970s, the effective cocoa duty rates were punitive, and the overvalued exchange rate further hurt the cocoa sector. Although some of the policy mistakes have been rectified and output has begun to recover, Ghana's cocoa sector is still below its peak levels.

The government has traditionally taxed cocoa by retaining export proceeds at the COCOBOD and by paying farmers a preset price in domestic currency. On the one hand, this practice helped to insulate domestic producers from short-term fluctuations in the international cocoa price, and the cocoa export duty remained an administratively simple and quantitatively important source of fiscal revenue. On the other hand, excessive explicit and implicit taxes on cocoa led to the smuggling of cocoa abroad.

The paper argues that international prices and the price incentive to smuggle (the GhanaCôte d'Ivoire price differential) can explain more of the short- and medium-term fluctuations than any other variable. A simple model of cocoa supply determination is described and estimated, using the cointegration and error-correction techniques for the sample period 1950-95. The speed of adjustment to long-run price changes is high: more than one-third of the deviation from the long-run equilibrium in the previous year translates into the current supply decisions made by farmers. Smuggling might have reduced the officially recorded supply of cocoa by 40,000-60,000 metric tons, that is, about one-half of the observed decline in output in the 1970s. We find, however, little evidence of domestic short-term substitution between cocoa and other crops. 


\section{REFERENCES}

Abbey, J.L.S., and C. Scott Clark, 1974, "A Macroeconometric Model of the Ghanaian Economy 1956-1969," Economic Bulletin of Ghana, Vol.4 (No.1), pp.3-32.

Abdulai, Awudu, and Peter Rieder, 1995, "The Impacts of Agricultural Price Policy on Cocoa Supply in Ghana: an Error Correction Estimation," Journal of African Economies, Vol. 4 (December), pp.315-35.

Akiyama, Takamasa, 1988, "Cocoa and Coffee Pricing Policies in Côte d'Ivoire," World Bank Policy, Planning, and Research Working Paper No. 64 (Washington: World Bank).

and Ronald C. Duncan, 1982, "Analysis of the World Cocoa Market," World Bank Staff Commodity Working Paper No. 8 (Washington: World Bank).

Azam, Jean-Paul, and Timothy Besley, 1989, "General Equilibrium with Parallel Market for Goods and Foreign Exchange: Theory and Application to Ghana," World Development, Vol. 17, No. 12, pp.1921-30.

Bateman, Merrill J., 1974, "An Econometric Analysis of Ghanaian Cocoa Supply," in The Economics of Cocoa Production and Marketing, ed. By R.A. Kotey, C. Okali, and B.E. Rourke (Legon, Ghana: Institute of Statistical, Social, and Economic Research). and others, 1990, "Ghana's Cocoa Pricing Policy," World Bank Policy, Research, and External Affairs Working Paper No. 429 (Washington: World Bank).

Berthelemy, Jean-Claude, and Christian Morrisson, 1987, "Manufactured Goods Supply and Cash Crops in Sub-Saharan Africa," World Development, Vol. 15 (October/November), pp. 1353-67.

Bevan, David, Paul Collier, and Jan Willem Gunning, 1989, Peasants and Governments: An Economic Analysis, (Clarendon Press: Oxford).

Bulír̆, Aleš, 1996, "Impact of Cocoa Taxation on Cocoa Supply in Ghana," in Ghana--Selected Issues and Statistical Annex, IMF Staff Country Report No. 96/69, by Michael Nowak and others (Washington: International Monetary Fund), pp.1-15.

Charemza, Wojciech W., and Derek F. Deadman, 1992, New Directions in Econometric Practice: General to Specific Modelling, Cointegration, and Vector Autoregression (Aldershot, England: Edward Elgar).

Coleman, Jonathan R., Takamasa Akiyama, and Panos N. Varangis, 1993, "How Policy Changes Affected Cocoa Sectors in Sub-Saharan Economies," World Bank Policy Research Working Paper No. 1129 (Washington: World Bank). 
Engle, Robert F., and C.W.J. Granger, 1987, "Cointegration and Error Correction:

Representation, Estimation, and Testing," Econometrica, Vol.55 (March), pp. 251-76.

Fosu, K. Yerfi, 1992, "The Real Exchange Rate and Ghana's Agricultural Exports," African Economic Research Consortium Research Paper 9 (Oxford: Center for the Study of African Economies).

Gyimah-Brempong, Kwabena, 1987, "Scale Elasticities in Ghanaian Cocoa Production," Applied Economics, Vol. 19 (October), pp.1383-90.

Jaeger, William K., 1992, "The Effects of Economic Policies on African Agriculture," World Bank Discussion Paper No. 147 (Washington: World Bank).

Johansen, Soren, and Katerina Juselius, 1990, "Maximum Likelihood Estimation and Inference on Cointegration, with Applications to the Demand for Money," Oxford Bulletin of Economics and Statistics, Vol.52, (May), pp.169-209.

Konings, Piet, 1986, The State and Rural Class Formation in Ghana: A Comparative Analysis (London: Routledge \& Kegan Paul).

May, Ernesto, 1985, "Exchange Controls and Parallel Market Economies in Sub-Saharan Africa: Focus on Ghana," World Bank Staff Working Paper No. 711 (Washington: World Bank).

Nowak, Michael, and others, 1996, Ghana-Selected Issues and Statistical Annex, IMF Staff Country Report No. 96/69 (Washington: International Monetary Fund).

Roe, Alan, and Hartmut Schneider, 1992, Adjustment and Equity in Ghana (Paris: Development Center of the Organization for Economic Cooperation and Development).

Sheikh, Munir A., 1989, "A Theory of Risk, Smuggling and Welfare," World Development, Vol. 17, No.12, pp.1931-44.

Stryker, J. Dirck, and others, 1990, Trade, Exchange Rate, and Agricultural Pricing Policies in Ghana, World Bank Comparative Studies (Washington: World Bank).

Tabatabai, Hamid, 1986, "Economic Decline, Access to Food and Structural Adjustment in Ghana," World Employment Program Research Working Papers, WEP10-6/WP80 (Geneva: International Labor Organization).

Weymar, Helmut F., 1968, The Dynamics of the World Cocoa Market, (Cambridge, Massachusetts: The M.I.T. Press). 
Wilson, P.R.D., 1984, "Ghana and the International Cocoa Market 1956-1969: A Simulation Model," Economic Modelling, Vol. 1 (July), pp.327-44.

World Currency Yearbook (New York: International Currency Analysis, Inc.), various issues.

Yeung, Patrick, Peter Pollak, and Suzana Augusto, 1979, “An Econometric Model of the Market for Cocoa Beans," World Bank Commodity Note No. 11, (Washington: World Bank). 